\title{
Inventory of the chemicals and the exposure of the workers' skin to these at two leather factories in Indonesia
}

\author{
Sri Awalia Febriana · Frank Jungbauer • \\ Hardyanto Soebono $\cdot$ Pieter-Jan Coenraads
}

Received: 9 December 2010/ Accepted: 9 September 2011/Published online: 22 September 2011

(c) The Author(s) 2011. This article is published with open access at Springerlink.com

\begin{abstract}
Purpose Tannery workers are exposed to hazardous chemicals. Tannery work is outsourced to newly industrialized countries (NICs) where attention into occupational health hazards is limited. In this study, we investigated the skin exposure to hazardous chemicals in tannery workers and determined the prevalence of occupational skin diseases (OSDs) at tanneries in a NIC.

Methods A cross-sectional study on the observation of the working process and an inventory and risk assessment of the chemicals used. Classification of chemicals as potential sensitizers/irritants and a qualitative assessment of exposure to these chemicals. Workers were examined and interviewed using Nordic Occupational Skin Questionnaire-2002/LONG.

Results The risk of OSDs at the investigated tanneries was mainly related to the exposure of the workers' skin to chemicals in hot and humid environmental conditions. In 472 workers, $12 \%$ reported a current OSD and 9\% reported a history of OSD. In $10 \%$ of all cases, an OSD was confirmed by a dermatologist and $7.4 \%$ had an occupational contact dermatitis (OCD). We observed that personal protective equipment (PPE) used was mainly because of skin problems in the past and not as a primary protection against OSD.
\end{abstract}

S. A. Febriana $\cdot$ H. Soebono

Department of Dermatology \& Venereology,

Gadjah Mada University, Yogyakarta, Indonesia

S. A. Febriana $(\bowtie) \cdot$ F. Jungbauer · P.-J. Coenraads Department of Dermatology, University Medical Centre Groningen, University of Groningen, Hanzeplein 1, P.O. Box 30 001, 9700 RB Groningen, The Netherlands e-mail: S.A.Febriana@derm.umcg.nl
Conclusion We observed a high frequency and prolonged exposure to many skin hazardous factors in tannery work although PPE was relatively easily available and which was generally used as a secondary preventative measure. The observed point-prevalence in this study was at the same level as that reported for other high-risk OSDs in Western countries and other tanneries in NICs. However, the observed point-prevalence in this study was lower than that reported in India and Korea. The results of our study and those of other studies at tanneries from other NICs were probably influenced by Healthy Worker Survivor Effect (HWSE).

Keywords Occupational skin diseases · Tannery workers - Skin exposure

\section{Introduction}

Chemicals used in leather manufacturing are intended to chemically alter the structure of the animal hides and may have the same effect on the human skin. These chemicals are potential irritants and sensitizers in workers who are frequently exposed to these for prolonged periods of time (Kolomaznik et al. 2008; Geier 2004). Occupational skin diseases in the leather industry are rarely reported despite their potential high risk. In a study from 1960 to 1969 among male workers in Sweden, it was reported that $12 \%$ of those suspected of occupational dermatitis and sensitized to chromium were tannery workers (Fregert 1975). Recent reports on properly conducted occupational dermatological surveys in this industry are virtually absent. This situation may be the result of outsourcing leather manufacturing to newly industrialized countries (NIC: a country once designated as less developed, but which has undergone recent, rapid industrialization) where attention into occupational 
health hazards is limited. Trade and financial changes because of globalization have been associated with an increasing outsourcing and subcontracting of hazardous work from developed to developing countries. The burden of diseases from occupational hazards associated with globalization is difficult to determine. Occupational illness is less likely to be detected in developing countries partly as a result of inadequate occupational health services (London and Kisting 2002). Developing countries generally have fewer adequately effective occupational health programs and fewer adequately developed and enforced laws and regulations than those in the developed countries (Levy 1996). This may be a reason why tannery work is not reported in statistics on occupational dermatoses in highrisk occupations (Athavale et al. 2007). Another reason for the absence of occupational skin disease data in tanneries may be the extensive automation implemented in this industry as long as it remained in developed countries (Geier 2004). By outsourcing leather manufacturing, the occupational health risks that come along with it are also outsourced. Indonesia is one of the newly industrialized countries (NICs) with 586 leather factories operating in 2003 that produced leather for the European market. These factories use a combination of traditional and modern technologies (Centre for Leather 2004). Although tanning industry has been present in Indonesia for several decades, there are no statistics on occupational skin diseases among tannery workers in Indonesia. A careful investigation of representative workplaces and examination of the workers is imperative to establish the actual risk of occupational skin diseases in leather manufacturing industry.

The purpose of this study was to investigate the nature of exposure and the occurrence of occupational skin diseases in workers in leather manufacturing industry in a NIC. An inventory of the chemicals to which the workers and the potential consumers may be exposed was compiled.

\section{Materials and methods}

A survey to obtain information on the working process and the skin exposure followed by a cross-sectional study to assess the prevalence of occupational skin diseases was conducted between March and December 2009 at two tanneries (one in Magelang, Central Java and one in Sidoarjo Industrial Area, East Java, Indonesia). We did not undertake random sampling because of the paucity of occupational health information in this industry. In order to get an overview of the working conditions in Indonesian tanneries, we selected one tannery that represented a highly mechanized and one that represented a medium mechanized plant according to the list provided by the Indonesian Centre for Leather (Centre for Leather 2004).
All employees engaged in the production process and exposed to potentially hazardous chemicals were included in the study. A summary of the research flow is shown in Fig. 1.

Observation of the workplace

Preceding the cross-sectional study of skin symptoms and signs, the different work stations of the factories were observed with regard to the nature of skin exposures to occupational hazards according to guidelines by Rycroft (2004). Workplace observation was done by an occupational dermatologist. This included the following:

1. Observing and making a detailed report on the working process in the factories. At each working stage, we interviewed responsible personnel and recorded the number of workers involved, job tasks, the duration and the frequency of exposure and indoor microclimates with a potential risk of causing occupational dermatoses.

2. Observing system of work, handling procedures, personal protective equipment (PPE) and skin care products.

3. Surveying the chemicals warehouse, chemicals being used in workplace and interviewing the workers and their supervisors. Chemical product lists and material safety data sheets (MSDS) were collected from the tannery and from the manufacturers of the chemicals. Information was collected from the researchers and the database at the Centre for Leather, Rubber and Plastic Agency for Research and Development, Ministry of Industry and Trade, Republic of Indonesia.

4. Listing of chemicals (including the CAS numbers of all ingredients), the workers are exposed to during the working process. The potential risk of all chemicals as a skin irritant or a skin sensitizer was assessed using the MSDS, the National Institute for Occupational Safety and Health Institute (NIOSH) website (NIOSH 2010), reference books (de Groot 2008) and a search using PubMed.

Questionnaire study and physical examination

A trained interviewer interviewed each exposed employee. All subjects gave their informed consent prior to their inclusion in the study. The interviewers were anthropologists and medical students who were trained in interviewing skills by an occupational dermatologist. The interviews were guided by using the Nordic Occupational Skin Questionnaire 2002 long version (NOSQ-2002/LONG). Since the level of education and the reading skills of the workers were limited, the interviewers explained the questions in the 


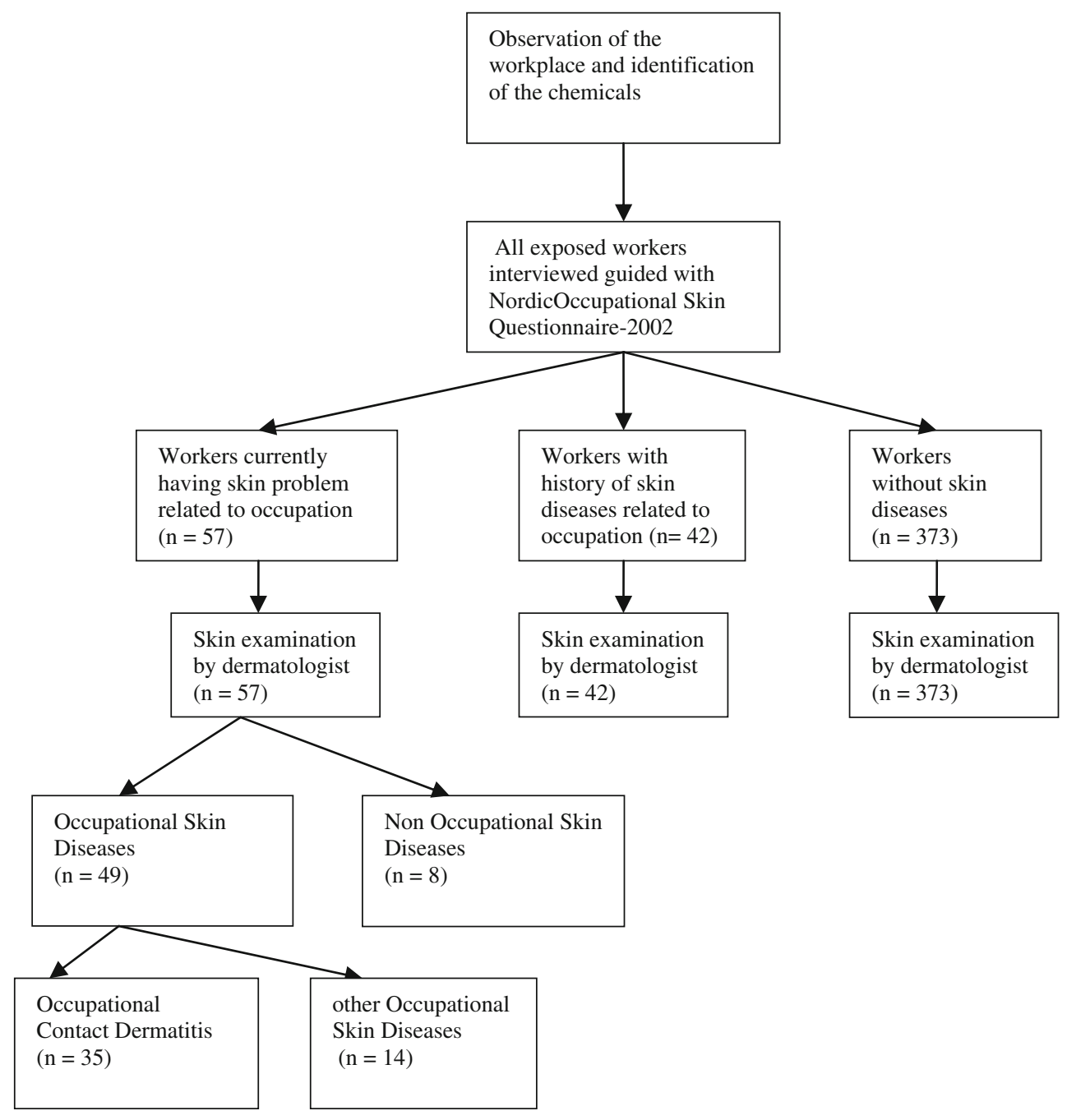

Fig. 1 Research flow

questionnaire without giving a personal interpretation of the response. In accordance with the NOSQ procedures, the questionnaire was translated, adapted and modified for the specific circumstances in tanneries in Indonesia following the guideline from Nordic Occupational Skin Questionnaire Group (Flyvholm et al. 2002). Adaptations were made on the question regarding location of the eczema (question D2), the specification of the workstation (question G1) and the list of chemicals the workers were exposed to (question G10). Since the interpretation of the English term 'eczema' in the Indonesian language is diverse, we decided to alter the term 'eczema' in the questionnaire with 'Have you had any skin problem related to occupation?'

Besides the questionnaire, the skin of all included workers was examined by two dermatologists and a dermatologist with additional training in contact and occupational dermatitis to determine the prevalence of occupational skin diseases. This assessment was put forward as a series decisions: (1) classify as dermatitis and not psoriasis, tinea or scabies; (2) classify as contact dermatitis and not atopic, seborrhoeic, discoid, stasis or unclassified; and (3) define the probable (occupation related) causes (Rycroft 1996).

\section{Results}

Working process and list of chemicals that the workers were exposed to

The leather processing itself involves three steps:

1. Preparation of hides (curing, soaking and hair removal liming) and pre-tanning stage (bating and pickling) in a special shed (called beam house).

2. Tanning stage (tanning, sammying and shaving). 
3. Post-tanning or finishing stage (drying, fat liquoring and finishing).

The working process and the relevant chemicals that the workers were exposed are shown in Fig. 2. List of chemicals and the effect of each chemical on the skin are presented in Table 1 .
Preparation of the hides and pre-tanning at the beam house

The aim of the beam house process is to put the hides into a proper chemical and physical condition for the subsequent removal of unwanted substances in the finished leather. In a curing process, the hides are treated with sodium chloride

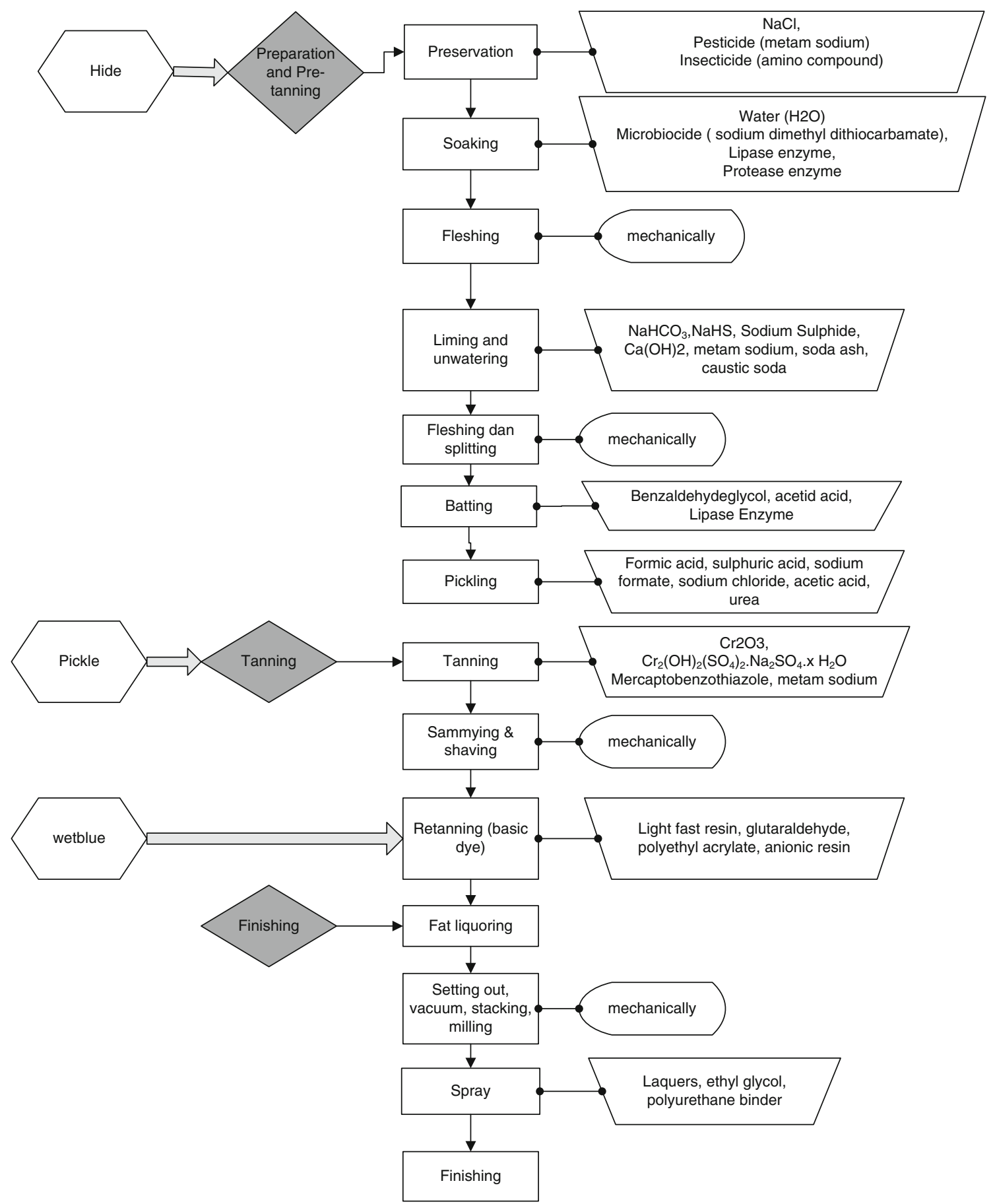

Fig. 2 Flowchart of working process 
Table 1 List of the chemicals and their effect on the skin

\begin{tabular}{|c|c|c|}
\hline & Chemicals used & Sensitizer/irritant \\
\hline \multicolumn{3}{|c|}{ Preparation of the hides in the beam house } \\
\hline \multirow[t]{5}{*}{ Preservation } & Sodium chloride & Irritant \\
\hline & Metam sodium & Irritant and \\
\hline & 2-n-Octyl-4-isothiazolin-3-one & sensitizer \\
\hline & $\mathrm{Cl}+\mathrm{Me}$-Isothiazolinone & Sensitizer \\
\hline & & Sensitizer \\
\hline \multirow[t]{6}{*}{ Soaking } & Water & Irritant \\
\hline & Lipase enzyme & - \\
\hline & Protease enzyme & - \\
\hline & Metam sodium & Irritant and \\
\hline & Sodium dimethyldithiocarbamate & sensitizer \\
\hline & & Sensitizer \\
\hline \multirow{2}{*}{$\begin{array}{l}\text { Green } \\
\text { fleshing }\end{array}$} & - & - \\
\hline & Sodium sulphide & Irritant \\
\hline \multirow{4}{*}{$\begin{array}{l}\text { Liming and } \\
\text { watering }\end{array}$} & Sodium hydrosulphide & Irritant \\
\hline & Lime & Irritant \\
\hline & Soda ash & Irritant \\
\hline & Caustic soda & Irritant \\
\hline Fleshing & - & - \\
\hline Splitting & - & - \\
\hline \multicolumn{3}{|c|}{ Pre-tanning section } \\
\hline \multirow[t]{3}{*}{ Deliming } & Hydrogen peroxide & Sensitizer, \\
\hline & Carbon dioxide & irritant \\
\hline & & Irritant \\
\hline \multirow[t]{3}{*}{ Bating } & Benzaldehyde glycol & Sensitizer \\
\hline & Acetic acid & Irritant \\
\hline & Lipase enzyme & - \\
\hline \multirow[t]{5}{*}{ Pickling } & Formic acid & Irritant \\
\hline & Sulphuric acid & Irritant \\
\hline & Sodium formate & Sensitizer \\
\hline & Sodium chloride & Irritant \\
\hline & Sodium metabisulphite & Sensitizer \\
\hline \multicolumn{3}{|l|}{ Tanning section } \\
\hline \multirow[t]{15}{*}{ Tanning } & Potassium dichromate & Sensitizer \\
\hline & 2-Mercaptobenzothiazole & Sensitizer \\
\hline & Metam sodium & Sensitizer \\
\hline & Acetic acid & Irritant \\
\hline & Aluminium sulphate & Irritant \\
\hline & Formaldehyde & Sensitizer \\
\hline & Polyethyl acrylate & Sensitizer \\
\hline & Glycine & Sensitizer \\
\hline & Chlorobenzene & Sensitizer \\
\hline & Oxalic acid & Sensitizer and \\
\hline & Vegetable tanning (mimosa & irritant \\
\hline & extract) & Sensitizer \\
\hline & Urea formaldehyde & Sensitizer \\
\hline & Glutaraldehyde & Sensitizer \\
\hline & Sodium dimethyldithiocarbamate & Sensitizer \\
\hline Sammying & - & - \\
\hline Shaving & - & - \\
\hline
\end{tabular}

Table 1 continued

\begin{tabular}{lll}
\hline & Chemicals used & Sensitizer/irritant \\
\hline $\begin{array}{l}\text { Finishing } \\
\text { Fat liquoring }\end{array}$ & $\begin{array}{l}\text { Vegetable oil (free phenol } \\
\text { compound) } \\
\text { Dyeing }\end{array}$ & $\begin{array}{l}\text { Disperse orange } 3 \\
\text { Acid yellow 36 }\end{array}$ \\
& Phenylenediamine & Sensitizer \\
& Hydrogen peroxide & Sensitizer \\
& Benzidine & Sensitizer \\
Finishing & Epoxy resin & Sensitizer \\
& Polyethylacrylate & Sensitizer \\
& Formaldehyde & Sensitizer \\
& Colophony & Sensitizer \\
& 4-tert-buthylphenol formaldehyde & Sensitizer \\
& resin & Sensitizer \\
\hline
\end{tabular}

and metam sodium. The salted hides are soaked to restore their natural humidity using a micro-biocide and enzymes. Hair removal/liming is done to remove the epidermis, hair and skin appendices. Hides are put in drums filled with lime, metam sodium as pesticide and sodium sulphide to achieve the alkaline condition, which destroys the epidermal keratin. Hair and skin appendices are also removed manually with fleshing knives and a rotating knives cylinder.

In pre-tanning section, hides are undergone de-liming, bating and pickling. De-liming is done to remove excessive lime using hydrogen peroxide and carbon dioxide. Bating is the next step to remove excess hair using a protease enzyme and to remove natural fat (degreasing) using a lipase enzyme. Finally, the hide is transferred into an acid condition (pickling) using formic acid, sulphuric acid, sodium formate, sodium chloride and sodium metabisulphite. The skin of the worker is exposed to sodium chloride, sodium formate and sodium metabisulphite in this step. Sodium chloride may dehydrate the worker's skin. Sodium metabisulphite is a skin sensitizer (Kaaman et al. 2010; Madan et al. 2007; Sasseville and El-Helou 2009). Sodium chloride, sodium sulphide, soda ash, caustic soda, acetic acid, formic acid and sulphuric acid have an irritant effect on the skin (NIOSH 2010; de Groot 2008). Metam sodium is a skin irritant (Koo et al. 1995) and contact sensitizer (Pruett et al. 2001).

\section{Tanning stage}

Tanning is the chemical process to convert the hides into tanned leather by stabilizing the collagen structure, protecting the leather from enzymatic degradation, enhancing the strength and increasing its resistance to heat, hydrolysis and microbial degradation. Trivalent chromium sulphate is 
the most widely used tanning agent to form cross-linking collagen. Although our factories also performed vegetable tanning (using a mimosa wattle extract), they normally used potassium dichromate and phenosulphonic acid formaldehyde, together with mercaptobenzothiazole and metam sodium as a biocide. Sodium bicarbonate is added to stabilize the collagen. Reducing the water content (sammying) and shaving of the pickled hides are done mechanically.

Chromate allergy is frequently observed in tannery workers (Athavale et al. 2007; Dickel et al. 2002; Hansen et al. 2002). Contact allergy to flower and leaf extract of the mimosa tree (Guin et al. 1999) and urea formaldehyde resin has also been reported (Sommer et al. 1999).

\section{Finishing stage}

In a post-tanning process, semi-finished leather undergoes dyeing, fat liquoring and coating to create elasticity, softness, impermeability and brightness of the tanned leather. Fat liquoring is used to soften the fibres of the hides and to increase water resistance using sulphonated oil. The coloured and fat-liquored leather is treated in a setting-out machine to make them smoother and then placed in a vacuum dryer to dehydrate the leather. After the drying process, the skin fibres have bonded to each other causing the hardening of the leather. Therefore, staking is done to soften the leather using a heavily vibrating metal pin. Leather is then stretched and pulled on a metal frame (toggling) and undergoes a trimming process to remove the unwanted parts of the hide. The last step in the finishing stage is the application of a protective and decorative coating. A water-based dye containing an anionic azo-dye is applied, which binds to the cationic surface of the leather and is completed with formic acid and acetic acid. A benzidine-based dye also used in one of these factories. Polyethylene acrylate, polyurethane, nitrocellulose and biocide are added if needed. In this stage, workers are exposed to different sensitizers such as azo-dyes, acrylates, formaldehyde and glutaraldehyde (Dickel et al. 2002; Ancona et al. 1982; Goon et al. 2008; Mancuso et al. 1996).

Work safety standards and the use of personal protective equipment (PPE)

Occupational dermatoses risk in tanneries is mainly related to the frequent and the prolonged exposure of the workers' skin to chemical substances, to hot and humid environmental conditions and to machinery equipment. Workers are exposed to hazardous chemicals through skin absorption, inhalation and ingestion.

Workers at the beam house and tanning area are exposed to chemicals during the whole process including cleaning and disposing the chemical wastes. During the process, chemicals emit fumes, mist, vapours or dust thus exposing the workers to airborne chemical pollutants. Personal protective equipment required by the workers in this area is gloves, apron, safety boots, goggles and respirator. Respirators were not available. Almost all the workers wore a thin plastic apron that did not cover all the parts of the body that were exposed to chemicals. They also wore plastic boots that covered the lower legs and the feet. Some workers, when holding a hide or pickled hide, used synthetic rubber gloves that covered their hands and lower arms. Some workers worked with bare hands and used a long metal tong.

In the finishing process, workers were exposed to chemical splashes, dust and mist, leather dust, paint spray and organic vapours. Some workers in the shaving and buffing area used cotton and leather gloves. Synthetic rubber gloves with inner cotton gloves were used by workers in the spraying and dyeing area. Workers who handled vacuum dryers, staking, spraying, sorting and measuring wore dust masks.

The majority of the workers practiced basic behavioural principles in personal protection such as refraining from eating, chewing, drinking and smoking in work areas. They washed the exposed skin areas thoroughly after handling chemicals. Moisturizers and hand creams were not available. Bathroom and dressing room were available at the observed tanneries. A description of the exposure to skin hazardous working circumstances is presented in Table 2. Despite this observation, we also noticed some reluctance against the use of PPE in this population. Especially the workers without skin problems were somewhat reluctant to use PPE, whereas workers with an OSD were more inclined to use PPE.

\section{Questionnaire study and physical examination}

Four hundred and seventy-two workers (112 women and 360 men) were enrolled into the study. Demographic characteristics of the workers are shown in Table 3. The prevalence of current occupational skin problems, based on the NOSQ, was $12 \%$ (it was reported by 57 workers-13 from beam house and pre-tanning, 18 from tanning and 26 from finishing process). Forty-two workers had a history of OSD (18 workers from the beam house and pre-tanning, 10 from tanning and 14 from finishing process) and 373 worker had no skin problems. The prevalence rate of current OSD based on the dermatological examination of the skin in this population was $10 \%$ (Table 4 ). The dermatological diagnoses of occupational related skin diseases are shown in Table 4. From all OSDs, occupational contact dermatitis had the highest prevalence in this study $(7.4 \%)$.

We observed that $59 \%$ of the workers with a past or present skin complaint and $49 \%$ of the healthy workers used gloves. Gloves were generally made of synthetic rubber 
Table 2 Description of exposure to skin hazardous working circumstances

\begin{tabular}{|c|c|c|c|c|}
\hline Area of operation & Potential hazards present & $\begin{array}{l}\text { PPE } \\
\text { required }\end{array}$ & $\begin{array}{l}\text { Availability of PPE } \\
\text { in the factory }\end{array}$ & Observation in worker practices \\
\hline $\begin{array}{l}\text { Preparation and pre- } \\
\text { tanning (beam house) }\end{array}$ & $\begin{array}{l}\text { Direct and airborne exposure to acids/ } \\
\text { alkalis in chemical dusts and mists } \\
\text { Pesticides } \\
\text { Bacteria }\end{array}$ & $\begin{array}{l}\text { Gloves } \\
\text { Safety } \\
\text { boots } \\
\text { Respirator } \\
\text { Goggles }\end{array}$ & $\begin{array}{l}\text { Gloves } \\
\text { Apron } \\
\text { Safety boots } \\
\text { Cotton masks }\end{array}$ & $\begin{array}{l}\text { Glove, apron cotton masks only used } \\
\text { by }<50 \% \text { of the workers } \\
\text { Safety boots used by all workers }\end{array}$ \\
\hline Tanning area & $\begin{array}{l}\text { Direct and airborne exposure to acids/ } \\
\text { alkalis in chemical dusts and mists }\end{array}$ & $\begin{array}{l}\text { Gloves } \\
\text { Apron } \\
\text { Safety } \\
\text { boots } \\
\text { Goggles } \\
\text { Respirator }\end{array}$ & $\begin{array}{l}\text { Gloves } \\
\text { Apron } \\
\text { Safety boots } \\
\text { Cotton masks }\end{array}$ & $\begin{array}{l}\text { Gloves, apron, safety boots used by } \\
50 \% \text { of the workers } \\
\text { Cotton masks only used by }<30 \% \text { of } \\
\text { the workers }\end{array}$ \\
\hline Finishing & $\begin{array}{l}\text { Injuries } \\
\text { Chemical splashes } \\
\text { Chemical dust and mist } \\
\text { Leather dust } \\
\text { Paint spray } \\
\text { Organic vapour } \\
\text { High humidity }\end{array}$ & $\begin{array}{l}\text { Gloves } \\
\text { Apron } \\
\text { Safety } \\
\text { boots } \\
\text { Goggles } \\
\text { Respirator }\end{array}$ & $\begin{array}{l}\text { Gloves } \\
\text { Apron } \\
\text { Cotton masks }\end{array}$ & $\begin{array}{l}\text { Gloves and cotton masks only used } \\
\text { by workers at dyeing section } \\
\text { Aprons used by almost all workers }\end{array}$ \\
\hline
\end{tabular}

Table 3 Demographic characteristics of the workers

\begin{tabular}{lcccc}
\hline Characteristics & $\begin{array}{l}\text { Preparation of beam } \\
\text { house and pre-tanning }\end{array}$ & Tanning & Finishing & Total \\
\hline Mean age in years (SD) & $39(10)$ & $37(9.8)$ & $35(9.8)$ & $36(9.6)$ \\
Sex & $101(28 \%)$ & $105(29 \%)$ & $154(43 \%)$ & 360 \\
Man $n(\%)$ & $10(8.9 \%)$ & $28(25 \%)$ & $74(66 \%)$ & 112 \\
Woman $n(\%)$ & $73(78)$ & $73(80)$ & $57(65)$ & $65(73)$ \\
Mean working in months (SD) & $6(29 \%)$ & $6(29 \%)$ & $9(43 \%)$ & 21 \\
History of childhood eczema $n(\%)$ & $21(33 \%)$ & $17(27 \%)$ & $26(41 \%)$ & 64 \\
Hand eczema in the last 12 months $n(\%)$ & $46(9.9)$ & $47(9.4)$ & $47(7.3)$ & $47(8.6)$ \\
Mean working hours/week (SD) & & & & \\
\hline
\end{tabular}

(49\%) and fabric materials (36\%). Other workers used polyvinyl chloride, cotton and leather gloves (Table 5).

\section{Discussion}

In our study, we were able to confirm the statement by Kolomaznik et al. that tannery workers have a high risk of exposure to metal salts (mainly chromates) at their workplace (Kolomaznik et al. 2008). Chemicals used in tanneries alter the structure of animal hide and therefore may have a damaging effect on the function and the structure to the worker's skin. We did not find large differences between the results of our cross-sectional survey on OSD with a high risk for OSD in Western countries (Gruvberger et al. 2003; Flyvholm et al. 2005; Attwa and el-Laithy 2009; Skudlik et al. 2009). However, in the observed tanneries, many typical hazardous situations were seen. In a spray-painting section, we saw workers without proper PPE working in small rooms with poor ventilation had a higher exposure to hazardous chemical vapours. Awareness of occupational health risk appeared to be low. Basic PPEs were available, but were mainly used as a secondary prevention measure. In many cases, small changes based on awareness of the health risk could decrease the risk of OSD dramatically. Activities of mixing the chemicals and painting the leather in openair-ventilated workplaces would considerably reduce the exposure to hazardous chemicals.

Similar to that reported in another study (Mellstrom and Boman 2004), we also observed the situation that gloves were mainly used to protect the already damaged skin. Lowering the prevalence of OSD could be achieved with 
Table 4 Result of the questionnaire and physical examination

\begin{tabular}{|c|c|c|c|c|}
\hline & $\begin{array}{l}\text { Preparation and } \\
\text { pre-tanning }(n=111)\end{array}$ & $\begin{array}{l}\text { Tanning } \\
(n=133)\end{array}$ & $\begin{array}{l}\text { Finishing } \\
(n=228)\end{array}$ & $\begin{array}{l}\text { Total } \\
(n=472)\end{array}$ \\
\hline Workers without skin problem (NOSQ-2002) & $80(72 \%)$ & $105(79 \%)$ & $188(83 \%)$ & $373(79 \%)$ \\
\hline $\begin{array}{l}\text { Workers currently reported skin problem related to occupation } \\
\text { (NOSQ-2002) }\end{array}$ & $13(12 \%)$ & $18(14 \%)$ & $26(11 \%)$ & $57(12 \%)$ \\
\hline $\begin{array}{l}\text { Workers with history of skin disease related to occupation } \\
(12 \text { months) (NOSQ-2002) }\end{array}$ & $18(16 \%)$ & $10(7 \%)$ & $14(6 \%)$ & $42(9 \%)$ \\
\hline $\begin{array}{l}\text { Workers with current occupational related skin disease } \\
\text { (according dermatological examination) }\end{array}$ & $11(10 \%)$ & $17(13 \%)$ & $21(9 \%)$ & $49(10 \%)$ \\
\hline \multicolumn{5}{|l|}{ Workers with occupational skin diseases } \\
\hline Occupational contact dermatitis & 6 & 13 & 16 & $35(7.4 \%)$ \\
\hline Pruritus & 1 & 3 & 1 & $5(1 \%)$ \\
\hline Miliria and foliculitis & 4 & 0 & 1 & $5(1 \%)$ \\
\hline Dermatophyte infection and intertrigo & 0 & 1 & 3 & $4(0.8 \%)$ \\
\hline
\end{tabular}

Table 5 Use of glove in the tanneries

\begin{tabular}{lll}
\hline & $\begin{array}{l}\text { Past or present skin } \\
\text { complaint }\end{array}$ & $\begin{array}{l}\text { No skin } \\
\text { complaint }\end{array}$ \\
\hline Glove use & $58(59 \%)$ & $181(49 \%)$ \\
No glove use & $41(41 \%)$ & $192(51 \%)$ \\
Total number of workers & 99 & 373 \\
\hline
\end{tabular}

substitution of hazardous substances, installation of the effective exhaust system, educational programme for workers and an effective use of PPE before skin problems arise.

From the questionnaire study, from the 472 workers, we noted 57 workers with a current skin complaint (a prevalence of $12 \%$ ), whereas $49(10 \%)$ of them had current occupation-related skin diseases diagnosed by a dermatologist with occupational contact dermatitis reported in 35 $(7.4 \%)$ workers. These results are in line with other NOSQ2002 validation surveys (Sommer et al. 1999; Attwa and elLaithy 2009; de Joode et al. 2007; Carstensen et al. 2006).

We found five published cross-sectional studies on tannery workers in three other newly industrialized countries: India, Argentina and Korea. Our results are higher than the prevalence reported from Buenos Aires (Kvitko 2001) and 2 Indian tanneries (Rastogi et al. 2008; Shukla et al. 1991). A survey conducted in Buenos Aires, reported in short communication, 440 of the 1,100 male tannery workers had occupational skin lesions (Kvitko 2001). Rastogi et al. (2008) reported $9 \%$ of the 197 male workers drawn randomly from 10 tanneries in India had skin rash and papules along with complaints of itching. A comprehensive occupational study was reported by Shukla et al. (1991) who selected 497 workers with stratified random sampling from 20 tanneries in an urban slum in India. They reported that $13(2.6 \%)$ workers had contact dermatitis and made quantification of the workplace hazards and PPE practices.

The point-prevalence in our study was lower than the reported point-prevalence of the $23 \%$ in a cross-sectional survey among 485 tannery workers in India (Ory et al. 1997) and 26\% in Korean tannery workers (Lee et al. 1991). Lee et al. (1991) performed a dermatological examination in 310 tannery workers with a prevalence of contact dermatitis of $26.4 \%$. They also reported other occupational related skin diseases like callus, paronychia, burn, physical trauma, vitiligo, joint deformity and oil acne.

The wide range of reported prevalence figures for OSD among tannery workers in newly industrialized countries (between 2.6 and 26.4\%) is probably caused by the differences in the definition of cases, period of screening and data collecting (Kvitko 2001; Rastogi et al. 2008; Shukla et al. 1991; Ory et al. 1997). Differences in the working conditions may also cause the wide range of reported pointprevalence.

Similar to that in other cross-sectional studies on occupational diseases, our results may be affected by a Healthy Worker Survivor Effect (HSWE). Workers who experience health problems are more likely to leave highexposure jobs, either by ending employment or being transferred. This may lead to the biased conclusion that the high-exposure occupation is safe (Siebert et al. 2001).

In this study, we were able to produce a detailed scheme of the working process with a focus on the risk of OSD in each step in tannery work. The difficulty in obtaining a random sample from tanneries in a NIC as the object of our study limits the interpretation of our data. Another limitation of our study is that we only have the qualitative data on the level of skin exposure to potentially hazardous chemicals. A quantitative assessment of exposure is necessary. In contrast to these limitations, we realize that this is one of the few studies on occupational skin disease risk 
in a NIC. More research into the effect of the occupational health risk of exporting such activities from Western countries to NIC is needed.

\section{Conclusion}

We observed a high frequency and a prolonged exposure to many skin hazardous factors in tannery work with a relatively easy availability of PPE, which was mostly used as a secondary prevention measure in a NIC. In this study, a point-prevalence of OSD was at the same level as that reported in other high-risk OSD in Western countries and some other tanneries in NICs. However, the observed point-prevalence in this study was lower than that reported in tanneries in India and Korea. The results of our study, as well as the results from other studies in this area, are probably substantially influenced by HWSE.

Conflict of interest The authors declare that they have no conflict of interest.

Open Access This article is distributed under the terms of the Creative Commons Attribution Noncommercial License which permits any noncommercial use, distribution, and reproduction in any medium, provided the original author(s) and source are credited.

\section{References}

Ancona A, Serviere L, Trejo A, Monroy F (1982) Dermatitis from an azo-dye in industrial leather protective shoes. Contact Dermatitis $8(3): 220-221$

Athavale P, Shum KW, Chen Y, Agius R, Cherry N, Gawkrodger DJ, EPIDERM (2007) Occupational dermatitis related to chromium and cobalt: experience of dermatologists (EPIDERM) and occupational physicians (OPRA) in the UK over an 11-year period (1993-2004). Br J Dermatol 157(3):518-522

Attwa E, el-Laithy N (2009) Contact dermatitis in car repair workers. J Eur Acad Dermatol Venereol 23(2):138-145

Carstensen O, Rasmussen K, Ponten A, Gruvberger B, Isaksson M, Bruze M (2006) The validity of a questionnaire-based epidemiological study of occupational dermatosis. Contact Dermatitis 55(5):295-300

Centre for Leather (2004) Academic background on national ecolabel criteria on leather of shoe upper, garment, glove and upholstery. Japan International Cooperation Agency (JICA) and Ministry of Environment (MOE) Republic of Indonesia, Indonesia

de Groot AC (2008) Patch testing: test concentration and vehicles for 4350 chemicals. A.C. de Groot publishing, The Netherlands

de Joode BW, Vermeulen R, Heederik D, van Ginkel K, Kromhout H (2007) Evaluation of 2 self-administered questionnaires to ascertain dermatitis among metal workers and its relation with exposure to metalworking fluids. Contact Dermatitis 56(6):311-317

Dickel H, Kuss O, Schmidt A, Diepgen TL (2002) Occupational relevance of positive standard patch-test results in employed persons with an initial report of an occupational skin disease. Int Arch Occup Environ Health 75(6):423-434
Flyvholm, Susitaival, Meding (2002) Nordic occupational skin questionnairre-NOSQ-2002. Nordic questionnaire for surveying work-related skin diseases on hands and forearms and relevant exposures. 518th Nordic Council of Ministers, Copenhagen, Denmark

Flyvholm MA, Mygind K, Sell L, Jensen A, Jepsen KF (2005) A randomised controlled intervention study on prevention of work related skin problems among gut cleaners in swine slaughterhouses. Occup Environ Med 62(9):642-649

Fregert S (1975) Occupational contact dermatitis in a 10-year material. Contact Dermatitis I:96-107

Geier A (2004) Leather and shoes. In: Kanerva A et al (eds) Handbook of occupational dermatology. Springer, Heidelberg, Germany, pp 637-643

Goon AT, Bruze M, Zimerson E, Goh CL, Soo-Quee Koh D, Isaksson M (2008) Screening for acrylate/methacrylate allergy in the baseline series: our experience in Sweden and Singapore. Contact Dermatitis 59(5):307-313

Gruvberger B, Isaksson M, Frick M, Ponten A, Bruze M (2003) Occupational dermatoses in a metalworking plant. Contact Dermatitis 48(2):80-86

Guin JD, Dwyer G, Sterba K (1999) Clothing dye dermatitis masquerading as (coexisting) mimosa allergy. Contact Dermatitis 40(1):45

Hansen MB, Rydin S, Menne T, Duus Johansen J (2002) Quantitative aspects of contact allergy to chromium and exposure to chrometanned leather. Contact Dermatitis 47(3):127-134

Kaaman AC, Boman A, Wrangsjo K, Matura M (2010) Contact allergy to sodium metabisulfite: an occupational problem. Contact Dermatitis 63(2):110-112

Kolomaznik K, Adamek M, Andel I, Uhlirova M (2008) Leather waste-potential threat to human health, and a new technology of its treatment. J Hazard Mater 160(2-3):514-520

Koo D, Goldman L, Baron R (1995) Irritant dermatitis among workers cleaning up a pesticide spill: California 1991. Am J Ind Med 27(4):545-553

Kvitko E (2001) Occupational contact dermatitis in the tanning industry. Contact Dermatitis 45(4):256

Lee JY, Kim YH, Kim HO, Kim CW (1991) Occupational dermatoses in tannery workers. The Kor J Occup Med 3(1):104-110

Levy BS (1996) Global occupational health issues: working in partnership to prevent illness and injury. AAOHN J 44(5):244-247 discussion 247

London L, Kisting S (2002) Ethical concerns in international occupational health and safety. Occup Med 17(4):587-600

Madan V, Walker SL, Beck MH (2007) Sodium metabisulfite allergy is common but is it relevant? Contact Dermatitis 57(3):173-176

Mancuso G, Reggiani M, Berdondini RM (1996) Occupational dermatitis in shoemakers. Contact Dermatitis 34(1):17-22

Mellstrom GA, Boman A (2004) Protective gloves. In: Kanerva L, Elsner P, Wahlberg JE, Maibach HI (eds) Condensed handbook of occupational dermatology. Springer, Berlin, pp 247-269

NIOSH (National Institute for Occupational Safety and Health) (2010) [http://www.cdc.gov/niosh/homepage.html] November/ 10

Ory FG, Rahman FU, Katagade V, Shukla A, Burdorf A (1997) Respiratory disorders, skin complaints, and low-back trouble among tannery workers in Kanpur, India. Am Ind Hyg Assoc J 58(10):740-746

Pruett SB, Myers LP, Keil DE (2001) Toxicology of metam sodium. J Toxicol Environ Health B Crit Rev 4(2):207-222

Rastogi SK, Pandey A, Tripathi S (2008) Occupational health risks among the workers employed in leather tanneries at kanpur. Indian J Dermatol Venereol Leprol 12(3):132-135

Rycroft RJG (1996) Clinical assessment in the workplace: dermatitis. Occup Med (Lond) 46(5):364-366 
Rycroft RJG (2004) Plant survey and inspection. In: Kanerva L, Elsner P, Wahlberg JE, Maibach HI (eds) Condensed handbook of occupational dermatology. Springer, Berlin, pp 437-440

Sasseville D, El-Helou T (2009) Occupational allergic contact dermatitis from sodium metabisulfite. Contact Dermatitis 61(4):244-245

Shukla A, Kumar S, Ory FG (1991) Occupational health and the environment in an urban slum in India. Soc Sci Med 33(5):597-603
Siebert U, Rothenbacher D, Daniel U, Brenner H (2001) Demonstration of the healthy worker survivor effect in a cohort of workers in the construction industry. Occup Environ Med 58(12):774-779

Skudlik C, Dulon M, Wendeler D, John SM, Nienhaus A (2009) Hand eczema in geriatric nurses in Germany-prevalence and risk factors. Contact Dermatitis 60(3):136-143

Sommer S, Wilkinson SM, Dodman B (1999) Contact dermatitis due to urea-formaldehyde resin in shin-pads. Contact Dermatitis 40(3):159-160 